\title{
Tehlikeli Araç Kullanma: Kamuda Çalışan Şoförlerin Emniyet Kemeri Kullanımı
}

\author{
Risky Driving: Understanding Seat Belt Use of Drivers \\ Working in Public Sector
}

\section{Dr. İsmail Cenk Demirkol - Asst. Prof. Dr. Hamza Tosun - Dr. Yusuf Yüksel}

\begin{abstract}
Öz
Bu çalışmanın amacı değişik koşullarda emniyet kemeri kullanımina etki eden faktörleri incelemektir. Sürücülerin emniyet kemeri kullanımı ile ilgili belirtmiş oldukları tutumlar ile çeşitli davranış ve tutumları incelenerek her ne kadar jandarma ve polis emniyet kemeri kontrolü yapsa da bazı sürücülerin neden emniyet kemeri kullanmadıkları anlaşılmaya çalışılmıştır. Sonuçlar, emniyet kemeri ve trafik güvenliğiyle ilgili programlar takip eden ve trafikte daha az heyecan arayan kişilerin daha büyük olasillkla emniyet kemeri kullandikların göstermiştir. Bununla birlikte, katılimcilarin saldirgan tutumları ve polis ve kameralarm varlığı da katılımciların bazı şartlarda emniyet kemeri kullanmalarına yol açtığını göstermiştir. Ancak, sonuçlar sürücülerin kaza geçirme ile ilgili algılarının emniyet kemeri kullanmalarına bir etkisinin olmadı̆̆ın göstermiştir.
\end{abstract}

Anahtar Kelimeler: Emniyet Kemeri Kullanım,, Heyecan Arayışı, Saldırganlık, Yaptırım

\begin{abstract}
The aim of this study is to examine the factors affecting drivers' seat belt use behaviors in different conditions. Drivers' self-reported seat belt use attitudes and behavioral and situational factors were examined to understand why some drivers do not wear seat belts; even though a mandatory seat belt law is enforced by police and gendarmerie. The results indicate that drivers who attend seminars, watch programs related to traffic safety on media and have lower sense of sensation seeking
\end{abstract}

are more likely to wear seat belt. Further, participants' sense of aggressiveness and presence of police and camera are found significant factor affecting drivers' seat belt use in specific driving conditions. However, the result indicated that drivers' risk perception regarding likelihood of being involved in traffic crashes is not related to seat belt use attitudes.

Keywords: Seat Belt Use, Sensation Seeking, Aggressiveness, Enforcement

\section{Introduction}

Drivers and passengers who hurt or killed in traffic crashes cause social and economic losses. One of the most feasible and influential method to avoid fatalities and economic losses is using seatbelts (Molnar et al., 2012). Seatbelts protect drivers and passengers by holding people in the vehicle during a crash including rollovers and reducing the likelihood of people to hit the hard surfaces in the vehicle (Evans, 1990). Experimental and empirical research examining the effectiveness of seat belt use on fatalities reveals that seat belts are important driving devices which save lives and reduce the risk of fatal injury to drivers and passengers (Evans, 1991, 1996; Cohen \& Einav, 2003; Cummings et al., 2003). For example, in a study, Evans (1986) found that seatbelts are overall $41 \%$ effecting in preventing fatalities for drivers and right front passengers. Another study conducted by Evans and Frick (1986) show that effectiveness of seatbelts in preventing fatalities reaches $62 \%$ for single-car

Dr. İsmail Cenk Demirkol, Police Academy, icdemirkol@tugam.net Asst. Prof. Dr. Hamza Tosun, Police Academy, htosun@tugam.net Dr. Yusuf Yüksel, Police Academy, yyuksel@tugam.net 
crashes, whereas seatbelts effectiveness is $30 \%$ for crashes involving two cars. Seatbelts are also found to be useful and effective devices to reduce the risk of fatalities for the right and left rear passengers (Evans, 1988).

Although today almost all cars come with seatbelts which are important for saving lives of the drivers and passengers, existing literature on the prevalence of seat belt use suggests that some drivers and passengers tend not to use seatbelts. According to European Transport Safety Council (2010), it is estimated that about $88 \%$ of the drivers and front seat passengers and about $72 \%$ of the rear seats passengers in the European Union member states use seatbelts. However, the range of the prevalence of the seatbelt use by member countries goes from about $80 \%$ to $95 \%$ for drivers and front seat passengers and about 30\% to $80 \%$ for rear seat passengers. Further, while wearing seat belt is mandatory in all European Union Member countries, failure to wear seatbelt is one of the most leading factor causing fatalities of drivers and passengers with speeding and drink driving. The prevalence of seat belt use in the United States was about $82 \%$ with the range of $58 \%$ to $92 \%$ by state (Beck \& Schultz, 2009).

When it comes to developing countries, there is no sufficient data to evaluate prevalence of seat belt use. According to World Health Organization report (WHO, 2013 ), only $6 \%$ of the low income countries and only $43 \%$ of the middle income countries have data on seat belt wearing rates. According to the report, those countries also do not enforce laws on seat belt use, if any, strictly. Thus it could be argued that the prevalence of seat belt use is lower in these countries comparing to developed countries. For example, the prevalence of seat belt use is only $29 \%$ in Argentina, 57\% in Columbia, only $2 \%$ in Congo, and $27 \%$ in India. These results suggest that there is a need for more comprehensive, cross-cultural, and reliable data to evaluate traffic safety and behavior across the world.

\section{Turkey Context}

As mentioned earlier, seat belt use is the most effective way to save lives and reduce injuries in traffic crashes. It was shown that drivers and passengers can protect themselves from being injured or death by using this simplest device in traffic crashes. The data provided by the Turkish National Police (TNP) also supports this argument. The number of accidents involving death and personal injury were 110,803 in $2011,130,360$ in 2012, and 135,241 in 2013. Table 1 represents the number of the crashes in which police officers were able to identify whether the drivers were used seatbelt or not and percentages of fatalities by the seatbelt use. As it can be seen in the table, overall $27 \%$ of the drivers did not use a seatbelt during the crashes. Based on the data presented in the Table 1, it could be argued that individuals not wearing seat belt are more likely to die in traffic crashes than the drivers wearing seat belt. Although the percentage of the driver fatalities have dropped in the last three years, deaths in traffic crashes still remain one of the most common causes of death. Additionally, tickets for failure to wear a seatbelt are among the most common types of traffic fines. Police officers issued a total of 528,577 seatbelt tickets in 2013 across the Turkey.

Table 1. Number of Driver Fatalities in Turkey

\begin{tabular}{lccccccccc}
\hline & \multicolumn{3}{c}{$\mathbf{2 0 1 1}$} & \multicolumn{1}{c}{$\mathbf{2 0 1 2}$} & \multicolumn{3}{c}{2013} \\
\cline { 2 - 9 } & $\begin{array}{c}\text { Number of } \\
\text { Drivers }\end{array}$ & $\begin{array}{c}\text { Killed in } \\
\text { Crashes }\end{array}$ & $\%$ & $\begin{array}{c}\text { Number of } \\
\text { Drivers }\end{array}$ & $\begin{array}{c}\text { Killed in } \\
\text { Crashes }\end{array}$ & $\%$ & $\begin{array}{c}\text { Number of } \\
\text { Drivers }\end{array}$ & $\begin{array}{c}\text { Killed in } \\
\text { Crashes }\end{array}$ & $\%$ \\
\cline { 2 - 10 } $\begin{array}{l}\text { Seat belt } \\
\text { used }\end{array}$ & 2,163 & 42 & 1.9 & 2,185 & 26 & 1.2 & 4,589 & 32 & .7 \\
$\begin{array}{l}\text { Seat belt } \\
\text { not used }\end{array}$ & 705 & 88 & 12.5 & 783 & 63 & 8.0 & 2,015 & 73 & 3.6 \\
\hline
\end{tabular}


Despite all these facts and mandatory seatbelt use laws in Turkey, the prevalence of seat belt use in Turkey is low comparing to EU countries and other developed countries (Akbas et al., 2010). Although WHO report (2013) indicates that seat belt wearing rates are $50 \%$ for the drivers and front seat passengers in Turkey, previous research suggests inconsistent findings on the prevalence of seatbelt use in Turkey. One of the first study on the prevalence of seatbelt use in Turkey conducted by Turkish National Police (2014) in 1999. The study was conducted in Ankara, the capital of Turkey, by observing 40,587 drivers at 27 different junctions. The results suggest that seatbelts were used only $21 \%$ of the drivers $(8,557)$. Unfortunately, it was found in the same report that none of the rear seat passengers wore seatbelts.

A series of studies, examining the prevalence of seat belt use in Turkey, was conducted by Simsekoglu and Lajunen (2008a, 2008b, 2009). In the first study, drivers' and front seat passengers' seatbelt use were observed in two different phases in Ankara (Simsekoglu \& Lajunen, 2008a). The sample of the study consisted of 1670 drivers and 2293 front seat passengers for the first phase and 963 drivers and 435 front seat passengers for the second phase. The result of the first phase observation showed that overall 20\% drivers and $14 \%$ of the front seat passengers wore seatbelts on city roads and overall $35 \%$ the drivers and $33 \%$ of the front seat passenger wore seatbelt on the intercity roads. In the second phase, it was found that $39 \%$ of the drivers and $32 \%$ of the front seat passenger wore their seatbelt. The results suggest that women relative to men and older people relative to younger people are more likely to use seat belt.

In the second study, Simsekoglu \& Lajunen (2008b) interviewed with 221 participants including drivers and front seat passengers. Based on participants' selfreported seat belt use behaviors, about $46 \%$ of the participants stated that they always wear seat belt on the inner city roads, while about $74 \%$ of the participants wear seat belt outside the city. The results also showed that participants' attitudes varied regarding road conditions. The self-reported seat belt use rates were higher in bad weather (71\%) and nighttime $(62 \%)$ than in daytime $(45 \%)$ and in good weather (44\%). In the final study, Simsekoglu and Lajunen (2009) examined the seatbelt use rate with 252 drivers. Results of the study showed that the percentages of the drivers wearing seatbelt almost all the time was overall $36 \%$ as driver, $31 \%$ as front seat passenger, and $15 \%$ as rear seat passenger on city roads, whereas $60 \%$ as driver, $51 \%$ as front seat passenger, and $16 \%$ as rear seat passenger on outside city roads.

Porter et al. (2010) observed 1423 vehicles to examine the seatbelt use rate of drivers and children in Ankara. The findings indicated that overall $52 \%$ of the drivers wore seatbelt. Bilgic et al. (2011) conducted a study in Antalya, one of the major resort destinations, to examine the prevalence of the seat belt use among drivers. They observed drivers both in city centers and on an intercity road. It was found that about $50 \%$ of the drivers and overall $35 \%$ of the front seat passengers used seat belt in city centers. Further, the study indicated that the prevalence of seat belt use was higher among female drivers (65\%) than male drivers (47\%). When it comes to intercity roads, the result showed that about $66 \%$ of the drivers and $60 \%$ of the front seat passenger used seat belt.

Ozkan et al. (2012) conducted a study with a total of 990 drives in two cities, Afyon and Ankara. They collected data on drivers' self-reported seatbelt use. Further, they observed participants' actual seatbelt use before the data collection process so that drivers were not aware of being observed their seat belt use behaviors. The results show that $39 \%$ of the drivers interviewed in Afyon and 45\% drivers interviewed in Ankara reported that they always use seatbelt. However, the results of the observation indicated that only 47\% in Afyon and 70\% in Ankara of these participants actually use seat belt. In other words, the actual seat belt use was lower than self-reported seat belt use.

Another study on the seatbelt use was conducted by Demirer et al. (2012) with 1000 participants in Sakarya. The study indicated that $68 \%$ of the participants (28\% definitely use and $40 \%$ use) reported they wear seat belt. The result also suggested that the education level affects drivers' self-reported use of seat belt in Turkey. It was found that seat belt use was more common amongst drivers having graduate degree followed by drivers having college degree, high school degree and primary school degree respectively. Further, the results suggest that education level also has an effect on belief about seat belt protection. That is, higher the education level of the participant is, the more likely they see seat belt as a necessary tool to protect their life. 
These research suggest that highest self-reported seatbelt use rate was $74 \%$ on intercity roads. However, the highest seat belt use rate in Turkey is still lower than the seat belt use rate of developed countries. Despite the importance of seatbelt use in relation to prevention of fatalities in traffic crashes, predictors of drivers' seat belt use behavior in Turkey have received very little attention. While previous studies mostly focused on public attitudes toward seat belt use, this study examined public drivers' seat belt use behaviors whose daily average driving time is four hour during their eight-hour shift. Thus, it is important for researchers to examine the predictors of their non-use of seatbelt.

\section{The Model}

Researchers examine drivers' seatbelt use under the category of risky driving (Deffenbacher et al., 2001; Jonah, 1990, 1997; Jonah et al., 2001; Iversen, 2004; Fernandes et al., 2010). However, according to Fernadez et al. (2010) previous research on risky driving used general index of risky driving or used only one or two risky driving behaviors as dependent variable. Thus, the existing research does not allow researchers to examine the effect of predictors across the other risky driving behaviors comprehensively.

Existing literature suggests some attitudinal and situational factors which are related to drivers' risky driving behavior. Existing research shows that since it stimulates high sensation seekers to anticipate pleasurable sensations (Arnett, 1996), sensation seeking is related to drivers' risky driving behaviors (Xie \& Parker, 2002; Iversen \& Rundmo, 2002; Zuckerman, 2007; Fernandes et al., 2010). For example, Arnett (1994) and Arnett et al. (1997) found that sensation seeking is related to various types of traffic violations including speeding, racing another car, and passing another car in no-passing zone. Another factor found to be predictor of risky driving is aggressiveness (Lajunen et al., 1998; Deffenbacher et al., 2001; Deffenbacher et al., 2003; Xie \& Parker, 2002). Researchers found that aggressive drivers are more likely to involve traffic violations (Lajunen \& Parker, 2001; Ozkan \& Lajunen, 2005). According to Plight (1996, 1998), perceived risk consisting of the likelihood and the severity of losses is a determinant of precautionary behavior which people employ to reduce the possible losses. Researcher argued and found that the perceived risk of involving in accident and being in- jured also affects people's seat belt usage (Slovic et al. 1978; Swenson et al., 1985; Stasson \& Fishbein, 1990; Chaudhary et al., 2004).

Another factor researchers have examined includes the effect of intervention campaigns on risky driving behaviors (Ulleberg, 2002). Stead et al. (2005) examined the effect of a three-year mass media campaign to reduce speeding in Scotland. The result showed that the campaign caused participants to change their attitudes and beliefs about speeding in a positive manner. Researchers also examined the relationship between the effectiveness of enforcement of seat belt law and seat belt use rates (Campbell, 1988; Williams \& Wells, 2004). The research conducted in Elmira, New York, (Williams et al., 1987), in Modesto, California, (Lund et al., 1989), in North Carolina (Williams et al., 1996), and in New York State (Williams et al., 2000) showed that when the law was strictly enforced, it led people to comply seat belt use laws. Further, these research suggest that the majority of the public living in the research site showed sympathy for such programs. Further, Chaudhary et al. (2004) found that people having higher sense of perceived risk of being ticketed were more likely to wear seatbelts.

\section{Methodology}

\section{Participants}

The aim of this paper was to understand seat belt use of drivers working in public sector. Thus, the research was conducted in Ankara, capital of Turkey. Since it houses many public organizations and institutions, it has the most number of public drivers in Turkey. Researchers sought permission via gatekeepers (people who have access to population) from about 35 public organizations to conduct study and to create a diverse sample. However, less than half of the organizations showed their willingness to participate in the study. The respondents of this study were professional drivers of 13 different public organizations including ministries, their sub-agencies, regional agencies, and local municipalities located in Ankara. A total of 400 hundred surveys were delivered to participants working in these organizations. They mostly drive cars during their working hours. The number of returned usable survey was 349 with a response rate of 87 percent. All scales were measured based on the four-point Likert type scale $(1=$ Strongly Disagree to $4=$ Strongly Agree or $1=$ Never to $4=$ Always). The questionnaire was developed and adapted from 
earlier studies (Lajunen \& Summala, 1995; Lajunen \& Ozkan, 2011; Rundmo \& Iversen, 2004; Hennessy \& Wiesenthal, 1999; Deffenbacher et al, 2004; Freedman \& Goldstein, 1999). Results of the bivariate and multivariate analyses were presented after conducting principal component analyses and examining scale reliabilities (see appendix).

\section{Measures}

The dependent variable of this study is the participants self-reported seat belt use. Respondents were asked "Do you wear seat belt?" with the possible answers $1=$ =never and $4=$ always in six different situations including always wear, during short distances, on intercity routes, at high speed and in bad weather, with my supervisor, and in my private vehicle. Answers were recoded to create a dummy variable, in which 0 denotes to never and sometimes and 1 usually and always.

Four items sensation seeking scale was used to measure participants' attitudes related to activities in traffic. The intent of the scale is to measure whether participants seek novel or risky stimulation in traffic $(\alpha=.75)$. Aggressiveness was assessed by using two item scale. The scale was used to measure participants self-reported aggressive behaviors in the traffic $(\alpha=.54)$. An adapted single item from Rundmo \& Iversen (2004) was used to measure participants' traffic accident risk perception. Similar to participants self-reported seat belt use, this item was also recoded as a dummy variable indicating whether the subject perceive that he will involve in a traffic accident or not $(0=$ no and $1=$ yes). A scale to measure whether media affects participants' seat belt use behavior or not consisted of two items. The scale was used to examine the effect of viewing any programs on media and following any seminars related to traffic rather than a specific media campaign or activities $(\alpha=.73)$. A scale consisting of four items included in the study to measure whether the presence of police and cameras are related to participants' seat belt use $(\alpha=.89)$.

The study included three demographic and other variables. Education level of the study participants was coded as $0=$ high school or less and $1=$ bachelor's degree or higher. Participants' age was collected on a ratio scale ranging from 21 to 62 . Finally, the daily driving distance made by participants was measured on a ratio scale, too. The values of participants' daily driving distance ranged from $20 \mathrm{~km}$ to $250 \mathrm{~km}$.

\section{Results}

Descriptive statistics are represented in Table 2. According to Table 2, the mean age of the participants was 41 with a range from 21 to 62 . Ninety two percent of the participants were married. The lowest degree of education was primary school and the highest education degree was college or above. The most indicated education level of the participants was high school (51\%). The average seniority level of the participants was 18.81. Overall half of the participants indicated they worked 20 years or less in their department while the other participants stated they work 21 years or more in their department. Participants stated that they made about $125.64 \mathrm{~km}$ and drove vehicles overall four and half hour daily. When participants were asked about their seat belt use, the prevalence of self-reported seat belt use for the given conditions are $85 \%$ for always use seat belt, $70 \%$ for on short distances, $92 \%$ for on intercity routes, $89 \%$ for at high speed and in bad weather condition, $81 \%$ for while with my supervisor, and $84 \%$ for while using private vehicle. The results indicated that highest seat belt use falls in the situation of intercity routes as expected and as previous research conducted in Turkey indicated.

Table 3 presents the mean scores of participants' behaviors on test measures by seat-belt use. The result of the t-test analyses revealed significant differences between participants wearing seat belt and participants not wearing seat belt for "sensation seeking", "media interest", and "enforcement" scales in all models as expected. Participants wearing seat belt scored higher than participants not wearing seat belt on "media" and "enforcement" scales. However, participants not wearing seat belt rated significantly higher score for aggressiveness scale than participants wearing seat belt. The results indicated that there was a significant differences between the groups on aggressiveness in all models but "at high speed and in bad weather" model. Participants wearing seat belt indicated less aggressiveness score than participants not wearing seat belt. However, the results suggested no significant differences on risk perception scale between the groups.

Logistic regression analyses were used to examine factors affecting participants' seat belt use attitudes in two steps and in six models as shown in Table 4. In step one, only demographic variables age, education, and daily driving distance were entered in the 
Table 2. Descriptive Statistics of Participants ( $N=349)$

\begin{tabular}{|c|c|c|c|c|c|c|c|}
\hline Variable & & $\mathrm{N}$ & $\%$ & Mean & SD & Min & $\operatorname{Max}$ \\
\hline \multirow[t]{4}{*}{ Age } & $1=\leq 30$ years & 58 & 17 & 41.15 & 9.25 & 21 & 62 \\
\hline & $2=31-40$ years & 114 & 33 & & & & \\
\hline & $3=41-50$ years & 115 & 33 & & & & \\
\hline & $4 \geq 51$ and above & 62 & 19 & & & & \\
\hline \multirow[t]{3}{*}{ Marital Status } & Married & 322 & 92 & 1.08 & .28 & 1 & 3 \\
\hline & Single & 26 & 7 & & & & \\
\hline & Widow & 1 & .3 & & & & \\
\hline \multirow[t]{5}{*}{ Education } & Primary School & 22 & 6 & 3.10 & .99 & 1 & 5 \\
\hline & Secondary School & 54 & 16 & & & & \\
\hline & High School & 177 & 51 & & & & \\
\hline & Two Year College & 59 & 17 & & & & \\
\hline & College or Above & 37 & 11 & & & & \\
\hline \multirow[t]{4}{*}{ Years of Experience } & $1=\leq 10$ years & 84 & 24 & 18.81 & 9.60 & 1 & 43 \\
\hline & $2=11-20$ years & 129 & 37 & & & & \\
\hline & $3=21-30$ years & 103 & 30 & & & & \\
\hline & $4=\geq 31$ years & 33 & 10 & & & & \\
\hline \multirow[t]{3}{*}{ Daily Driving Distance } & $1=\leq 50 \mathrm{~km}$ & 60 & 17 & 125.64 & 73.44 & 20 & 250 \\
\hline & $2=51-100 \mathrm{~km}$ & 123 & 35 & & & & \\
\hline & $3=\geq 101 \mathrm{~km}$ & 166 & 48 & & & & \\
\hline \multirow[t]{2}{*}{ Daily Driving Time } & $0=\leq 4$ hours & 183 & 52 & 4.60 & 2.41 & 1 & 10 \\
\hline & $1=\geq 5$ hours & 166 & 48 & & & & \\
\hline \multirow[t]{2}{*}{ Always Wear } & $0=\mathrm{No}$ & 53 & 15 & .85 & .36 & 0 & 1 \\
\hline & $1=\mathrm{Yes}$ & 296 & 85 & & & & \\
\hline \multirow[t]{2}{*}{ During Short Distances } & $0=\mathrm{No}$ & 106 & 30 & .70 & .46 & 0 & 1 \\
\hline & $1=\mathrm{Yes}$ & 243 & 70 & & & & \\
\hline \multirow[t]{2}{*}{ On Intercity Routes } & $0=\mathrm{No}$ & 28 & 8 & .92 & .27 & 0 & 1 \\
\hline & $1=$ Yes & 321 & 92 & & & & \\
\hline \multirow{2}{*}{$\begin{array}{l}\text { At High Speed and in Bad } \\
\text { Weather }\end{array}$} & $0=\mathrm{No}$ & 38 & 11 & .89 & .31 & 0 & 1 \\
\hline & $1=\mathrm{Yes}$ & 311 & 89 & & & & \\
\hline \multirow[t]{2}{*}{ While with My Supervisor } & $0=\mathrm{No}$ & 67 & 19 & .81 & .39 & 0 & 1 \\
\hline & $1=\mathrm{Yes}$ & 282 & 81 & & & & \\
\hline While Using Private & $0=\mathrm{No}$ & 55 & 16 & .84 & .36 & 0 & 1 \\
\hline Vehicle & $1=\mathrm{Yes}$ & 294 & 84 & & & & \\
\hline
\end{tabular}

models. However, none of the model was significant in step one. In step two, predictor variables of the study were entered in the models. The full models show that sensation seeking $(\beta=.80, S E=.06, \mathrm{p}<.001)$ and media $(\beta=1.43, S E=.09, \mathrm{p}<.001)$ in "always wear" model; sensation seeking $(\beta=.87, S E=.05, \mathrm{p}<.01)$, media $(\beta=1.15, S E=.06, \mathrm{p}<.05)$, and enforcement $(\beta=1.09, S E=.04, \mathrm{p}<.05)$ in "during short distances" model; education $(\beta=4.43, S E=.71, \mathrm{p}<.05)$, sensation seeking $(\beta=.70, S E=.08, \mathrm{p}<.001)$ and media $(\beta=$ $1.68, S E=.14, \mathrm{p}<.001)$ in "on intercity routes" model; sensation seeking $(\beta=.79, S E=.07, \mathrm{p}<.001)$, media $(\beta$
$=1.64, S E=.11, \mathrm{p}<.001)$, and enforcement $(\beta=1.15$, $S E=.05, \mathrm{p}<.01)$ in "at high speed and in bad weather" model; aggressiveness $(\beta=.75, S E=.11, \mathrm{p}<.01)$ and media $(\beta=1.22, S E=.07, \mathrm{p}<.01)$ in "while with my supervisor" model; and sensation seeking ( $\beta=$ $.77, S E=.12, \mathrm{p}<.001)$, aggressiveness $(\beta=.80, S E=.08$, $\mathrm{p}<.05)$, and media $(\beta=1.05, S E=.05, \mathrm{p}<.001)$ "while using private vehicle" model were significant predictors of participants seat belt use behavior. With regard the personal characteristics and participants' risk perceptions, none of the factor was significant in any of the full model. 


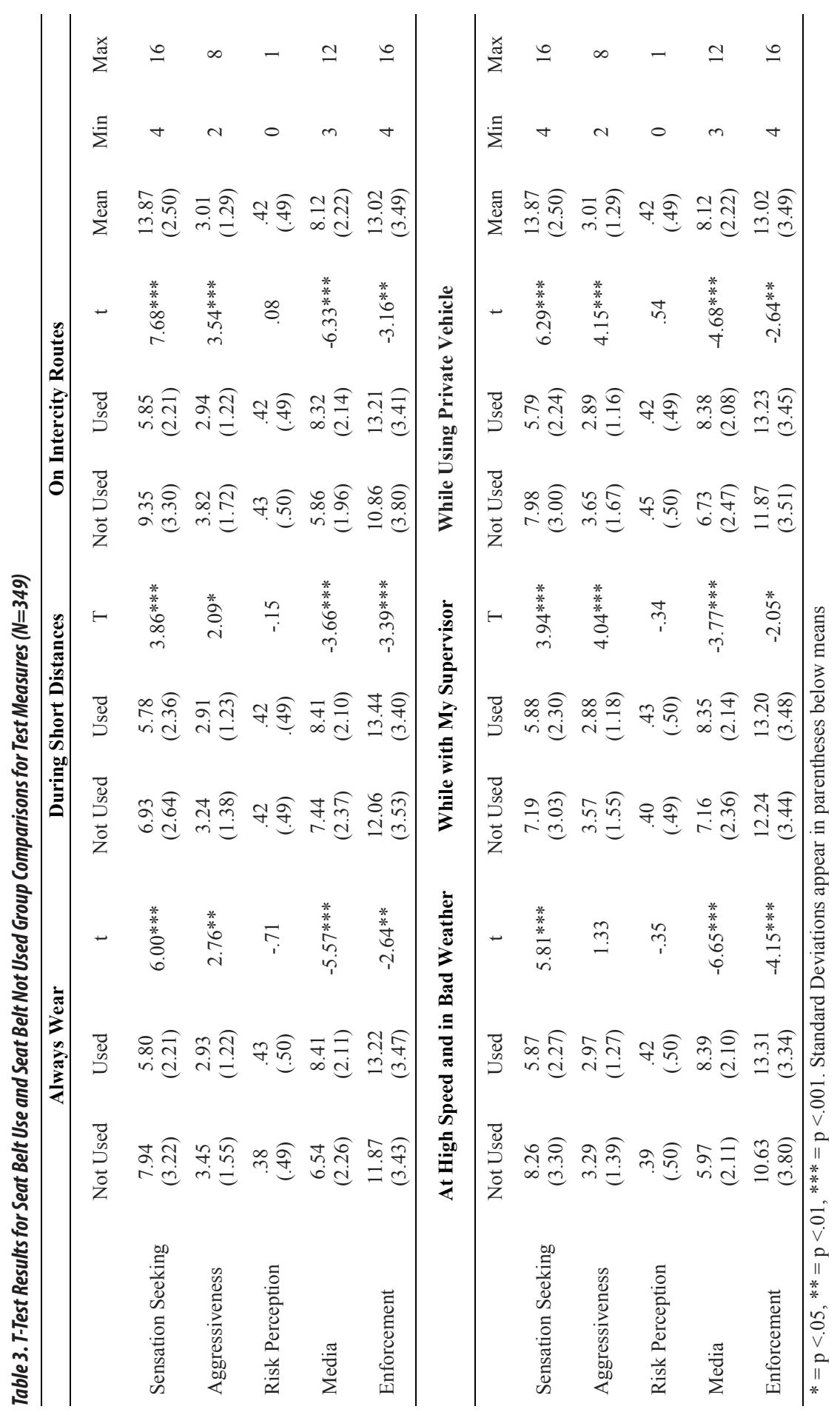




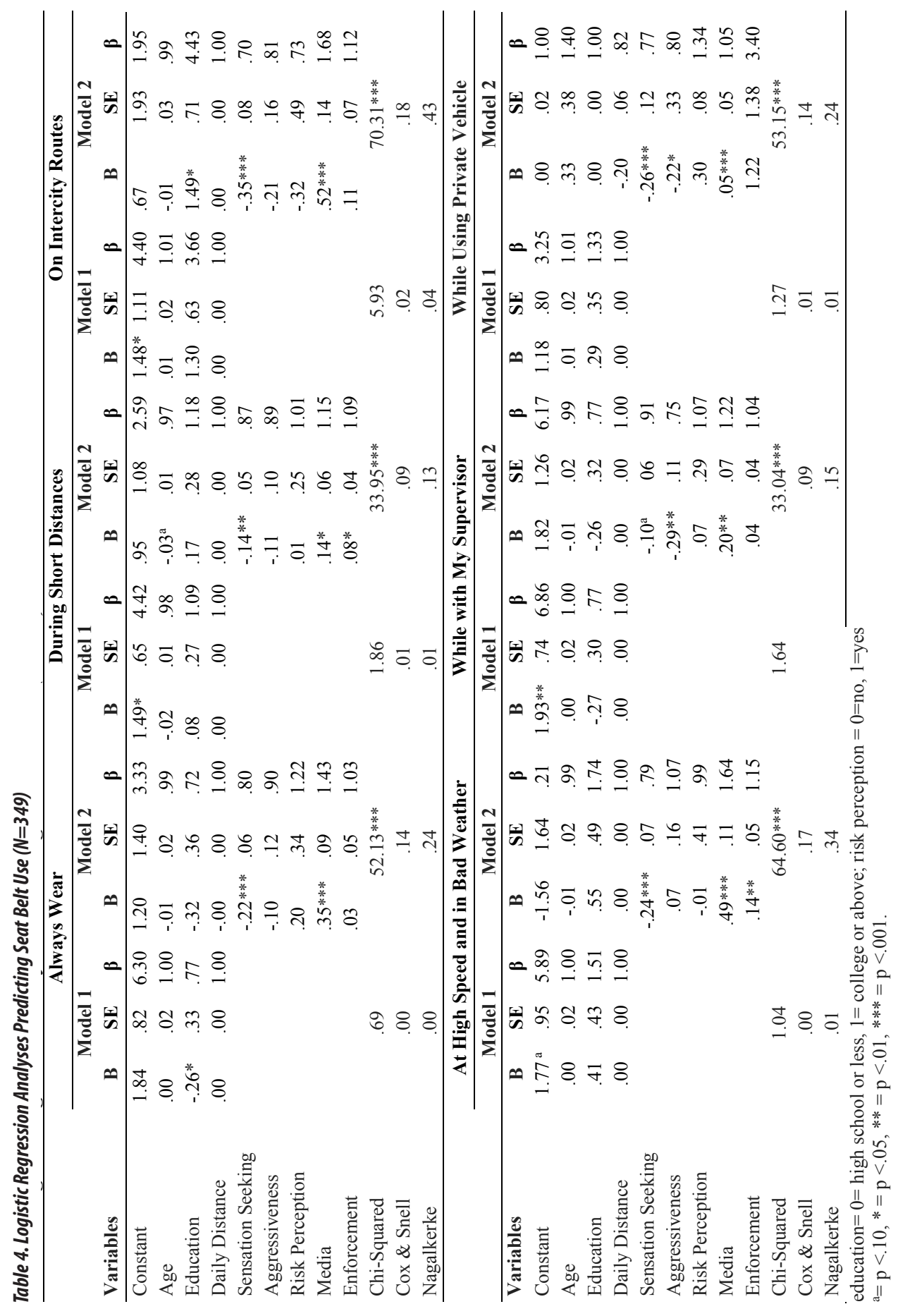


Aside from "while with my supervisor" model, sensation seeking is found negative and statistically significant in other models. Based on the results it could be argued that participants indicating higher levels of sensation seeking scores less likely to use seat belt. Further, the results suggest that participating traffic related seminars and programs on media was related to seat belt use in all models. In other words, those who follow those programs and seminars are more likely to use seat belt than those who do not follow seminars and programs on media.

Other factors being related to participants seat belt use were enforcement, aggressiveness, and education. The results indicated that participants scored high on enforcement scale were more likely to use seat belt in "during short distances" and "at high speed and bad weather" models; participants indicating higher scores on aggressiveness scale were less likely to use seat belt in "while with my supervisor" and "while using private vehicle" models; and participants having college or higher degree were more likely to use seat belt in "on intercity routes" model.

\section{Discussion}

According to Jonah (1986), people who don't wear seatbelts are the drivers who tend to be greater risk takers and more likely to involve more traffic crashes and other traffic violations. Thus, it could be argued that drivers' risky driving behaviors could be reduced in general by enhancing the prevalence of seat belt use among them. Most of the previous research on seat belt use did not control the various situations we have studied in this study.

One of the most important result of this study is that when these conditions are examined, drivers' attitudes toward seat belt use and factors affecting those attitudes vary. Our findings are partly consistent with the model. The results revealed that sensation seeking is an important factor related to drivers' seat belt use. As expected, participants showing higher scores on sensation seeking scale were less likely to use seat belt. Another predictor of seat belt use having been found in this study is participants' attitudes toward traffic related seminars and programs on media. Drivers following or attaining traffic related programs are more likely to use seat belt than those who do not follow or attain programs on traffic.

However, we find a partial support for predictors including aggressiveness and enforcement. We found also no significant relationship between seat belt use behaviors and drivers' risk perception. Further, in general none of the demographic variables contributed the models significantly. This is not to say that the variables aggressiveness and enforcement and other demographic characteristics have no effect on participants' seat belt use behaviors. We did not measure indirect effect of these variables on the seat belt use through other measures. Therefore, one of the point that future research need to examine is such relationship among study variables.

The primary implication of the research is that organizations can arrange seminars or in-service training for all staff especially drivers to cope with the root causes of their risky driving behaviors. Second, since the drivers' attitudes toward seat belt use and factors affecting those attitudes differ in various conditions, policy makers and researchers should consider different intervention programs and regulations to increase the prevalence of seat belt use for different situations. Further, those interventions may include media programs and seminars on traffic safety. Organizations may encourage their staff to follow and take part in those programs. By doing so, drivers and staff may change their attitudes towards risky driving behaviors. Ajzen (2005) noted that the more people engage in intentions toward their respective behavior, the more likely their behaviors become routine or habitual. Thus, the ultimate aim of those interventions should be drivers to use seatbelt as their routine. Finally, considering the increasing number of cars and vehicles on the road, more research must be conducted on drivers' risky driving behaviors.

This study has a couple of limitations. First, it should be noted that the existing literature on validity of self-reported seatbelt use suggest that drivers traditionally tend to over report their seatbelt use (Block, 2002; Ozkan et al., 2012). In other words the actual seatbelt use of the drivers are lower than their selfreported seatbelt use. We acknowledged that participants of the study might have over reported their seat-belt use. Further research could include drivers' actual seat belt use behaviors to examine predictors affecting drivers' risky driving behaviors including seat belt use. Another limitation of this study is that although this study included a wide variety of public organizations, researchers could include other departments to make more diverse population. 


\section{Acknowledgement}

This document has been produced with the help of a grant from The Global Road Safety Partnership a hosted project of the International Federation of Red Cross and Red Crescent Societies. The contents of this document are the sole responsibility of the authors and can under no circumstances be regarded as reflecting the positions of International Federation of Red Cross and Red Crescent Societies (IFRC) nor those of the Donors.

\section{References}

Ajzen, I. (2005). Attitudes, personality, and behavior. Maidenhead, England: Open University Press.

Akbas, O., Guven, R., Cebeci, G., Bertlek, S. B., Aldemir, G., \& Bal, E. (2010). A study on the effects of seat belt posters on drivers. Procedia-Social and Behavioral Sciences, 2(2), 1002-1007.

Arnett, J. J. (1994). Sensation seeking: A new conceptualization and a new scale. Personality and Individual Differences, 16 (2), 289-296.

Arnett, J. J. (1996). Sensation seeking, aggressiveness, and adolescent reckless behavior. Personality and Individual Differences, 20 (6), 693-702.

Arnett, J. J., Offer, D., \& Fine, M. A. (1997). Reckless driving in adolescence: 'State' and 'trait' factors. Accident Analysis \& Prevention, 29 (1), 57-63.

Beck, L. F., \& Shults, R. A. (2009). Seat belt use in states and territories with primary and secondary laws-United States, 2006. Journal of safety research,40 (6), 469-472.

Bilgic, S., Barut, H. B., Karacasu, M., Er, A., \& Yaliniz, P. (2011). The changes in usage of seat belts in Antalya, Turkey. Procedia-Social and Behavioral Sciences, 20, 588-593.

Block, A. W. (2002). 2000 motor vehicle occupant safety survey: Seat belt report. US Department of Transportation, National Highway Traffic Safety Administration.
Budd, R. J., North, D., \& Spencer, C. (1984). Understanding seat-belt use: A test of Bentler and Speckart's extension of the 'theory of reasoned action'. European Journal of Social Psychology, 14(1), 69-78.

Campbell, B. J. (1989). The association between enforcement and seat belt use. Journal of safety Research, 19(4), 159-163.

Chaudhary, N. K., Solomon, M. G., \& Cosgrove, L. A. (2004). The relationship between perceived risk of being ticketed and self-reported seat belt use. Journal of Safety Research, 35(4), 383-390.

Cohen, A., \& Einav, L. (2003). The effects of mandatory seat belt laws on driving behavior and traffic fatalities. Review of Economics and Statistics, 85(4), 828-843.

Cummings, P., Wells, J. D., \& Rivara, F. P. (2003). Estimating seat belt effectiveness using matched-pair cohort methods. Accident Analysis \& Prevention, 35(1), 143-149.

Deffenbacher, J. L., Lynch, R. S., Filetti, L. B., Dahlen, E. R., \& Oetting, E. R. (2003). Anger, aggression, risky behavior, and crash-related outcomes in three groups of drivers. Behaviour Research and Therapy, 41(3), 333-349.

Deffenbacher, J. L., Lynch, R. S., Oetting, E. R., \& Yingling, D. A. (2001). Driving anger: Correlates and a test of state-trait theory. Personality and Individual Differences, 31(8), 1321-1331.

Deffenbacher, J. L., Oetting, E. R., \& Lynch, R. S. (1994). Development of a driving anger scale. Psychological reports, 74(1), 83-91.

Demirer, A., Durat, M., \& Hasimoglu, C. (2012). Investigation of seat belt use among the drivers of different education levels. Safety science, 50(4), 1005-1008.

Dinh-Zarr, T. B., Sleet, D. A., Shults, R. A., Zaza, S., Elder, R. W., Nichols, J. L., Thompson, R. S., \& Sosin, D. M. (2001). Reviews of evidence regarding interventions to increase the use of safety belts. American Journal of Preventive Medicine, 21(4), 48-65. 
European Transport Safety Council (2010). 4th annual road safety performance index (PIN) report. Retrieved April 10, 2014, from http://etsc.eu/4thannual-road-safety-performance-index-pinreport/

Evans, L. (1986). The effectiveness of safety belts in preventing fatalities. Accident Analysis \& Prevention, 18(3), 229-241.

Evans, L. (1988). Rear seat restraint system effectiveness in preventing fatalities. Accident Analysis \& Prevention, 20(2), 129-136.

Evans, L. (1990). Restraint effectiveness, occupant ejection from cars, and fatality reductions. Accident Analysis \& Prevention, 22(2), 167-175.

Evans, L. (1991). Traffic safety and the driver. New York, NY: Van Nostrand Reinhold.

Evans, L. (1996). Safety-belt effectiveness: The influence of crash severity and selective recruitment. Accident Analysis \& Prevention, 28(4), 423-433.

Evans, L., \& Frick, M. C. (1986). Safety belt effectiveness in preventing driver fatalities versus a number of vehicular, accident, roadway, and environmental factors. Journal of Safety Research, 17(4), 143-154.

Fernandes, R., Hatfield, J., \& Soames Job, R. F. (2010). A systematic investigation of the differential predictors for speeding, drink-driving, driving while fatigued, and not wearing a seat belt, among young drivers. Transportation research part F: Traffic Psychology and Behaviour, 13(3), 179-196.

Freedman, P., \& Goldstein, K. (1999). Measuring media exposure and the effects of negative campaign ads. American Journal of Political Science, 11891208.

Hennessy, D. A., \& Wiesenthal, D. L. (1999). Traffic congestion, driver stress, and driver aggression. Aggressive Behavior, 25(6), 409-423.

Iversen, H. (2004). Risk-taking attitudes and risky driving behaviour. Transportation Research Part F: Traffic Psychology and Behaviour, 7(3), 135-150.

Iversen, H., \& Rundmo, T. (2002). Personality, risky driving and accident involvement among Norwegian drivers. Personality and Individual Differences, 33 (8), 1251-1263.
Jonah, B. A. (1986). Accident risk and risk-taking behaviour among young drivers. Accident Analysis \& Prevention, 18(4), 255-271.

Jonah, B. A. (1990). Age differences in risky driving. Health Education Research, 5(2), 139-149.

Jonah, B. A. (1997). Sensation seeking and risky driving: a review and synthesis of the literature. Accident Analysis \& Prevention, 29(5), 651-665.

Jonah, B. A., Thiessen, R., \& Au-Yeung, E. (2001). Sensation seeking, risky driving and behavioral adaptation. Accident Analysis \& Prevention, 33(5), 679-684.

Lajunen, T., \& Ozkan, T. (2011). Self-report instruments and methods. In B. E. Porter (Ed.), Handbook of Traffic Psychology (pp.43-59). San Diego, CA: Elseveir.

Lajunen, T., \& Parker, D. (2001). Are aggressive people aggressive drivers? A study of the relationship between self-reported general aggressiveness, driver anger and aggressive driving. Accident Analysis \& Prevention, 33 (2), 243-255.

Lajunen, T., \& Summala, H. (1995). Driving experience, personality, and skill and safety-motive dimensions in drivers' self-assessments. Personality and Individual Differences, 19(3), 307-318.

Lajunen, T., Parker, D., \& Stradling, S. G. (1998). Dimensions of driver anger, aggressive and highway code violations and their mediation by safety orientation in UK drivers. Transportation Research Part F: Traffic Psychology and Behaviour, 1(2), 107-121.

Lund, A. K., Stuster, J., \& Fleming, A. (1989). Special publicity and enforcement of California's belt use law: making a "secondary" law work. Journal of Criminal Justice, 17(5), 329-341.

Ozkan, T., \& Lajunen, T. (2005). Why are there sex differences in risky driving? The relationship between sex and gender-role on aggressive driving, traffic offences, and accident involvement among young Turkish drivers. Aggressive Behavior, 31(6), 547-558.

Ozkan, T., Puvanachandra, P., Lajunen, T., Hoe, C., \& Hyder, A. (2012). The validity of self-reported seatbelt use in a country where levels of use are low. Accident Analysis \& Prevention, 47, 75-77. 
Pligt, J. (1996). Risk perception and self-protective behavior. European Psychologist, 1(1), 34-43.

Pligt, J. (1998). Perceived risk and vulnerability as predictors of precautionary behaviour. British Journal of Health Psychology, 3(1), 1-14.

Porter, B. E., Lajunen, T., Ozkan, T., \& Will, K. E. (2010). A behavioral observation study of Turkish drivers' and children's safety belt use. Procedia-Social and Behavioral Sciences, 5, 1607-1609.

Rundmo, T., \& Iversen, H. (2004). Risk perception and driving behaviour among adolescents in two Norwegian counties before and after a traffic safety campaign. Safety Science, 42(1), 1-21.

Simsekoglu, O., \& Lajunen, T. (2008a). Environmental and psychosocial factors affecting seat belt use among Turkish front-seat occupants in Ankara: Two observation studies. Traffic injury prevention, 9(3), 264-267.

Simsekoglu, O., \& Lajunen, T. (2008b). Why Turks do not use seat belts? An interview study. Accident Analysis \& Prevention, 40(2), 470-478.

Simsekoglu, O., \& Lajunen, T. (2009). Relationship of seat belt use to health and driver behaviors. Transportation research part F: traffic psychology and behaviour, 12(3), 235-241.

Slovic, P., Fischhoff, B., \& Lichtenstein, S. (1978). Accident probabilities and seat belt usage: A psychological perspective. Accident Analysis \& Prevention, 10(4), 281-285.

Stasson, M., \& Fishbein, M. (1990). The relation between perceived risk and preventive action: A within-subject analysis of perceived driving risk and intentions to wear seatbelts. Journal of Applied Social Psychology, 20(19), 1541-1557.

Stead, M., Tagg, S., MacKintosh, A. M., \& Eadie, D. (2005). Development and evaluation of a mass media Theory of Planned Behaviour intervention to reduce speeding. Health Education Research, 20(1), 36-50.
Svenson, O., Fischhoff, B., \& MacGregor, D. (1985). Perceived driving safety and seatbelt usage. Accident Analysis \& Prevention, 17(2), 119-133.

Turkish National Police (2014). Emniyet kemeri neden gereklidir. Retrieved April 10, 2014, from http:// www.trafik.gov.tr/Sayfalar/EmniyetKemeriKullanimi.aspx

Ulleberg, P. (2002). Personality subtypes of young drivers: Relationship to risk-taking preferences, accident involvement, and response to a traffic safety campaign. Transportation Research Part F: Traffic Psychology and Behaviour,4(4), 279-297.

Williams, A. F., \& Wells, J. K. (2004). The role of enforcement programs in increasing seat belt use. Journal of Safety Research, 35(2), 175-180.

Williams, A. F., Lund, A. K., Preusser, D. F., \& Blomberg, R. D. (1987). Results of a seat belt use law enforcement and publicity campaign in Elmira, New York. Accident Analysis \& Prevention, 19(4), 243-249.

Williams, A. F., Reinfurt, D., \& Wells, J. K. (1996). Increasing seat belt use in North Carolina. Journal of Safety Research, 27(1), 33-41.

Williams, A. F., Wells, J. K., McCartt, A. T., \& Preusser, D. F. (2001). “Buckle up now!” An enforcement program to achieve high belt use. Journal of Safety Research, 31(4), 195-201.

Xie, C., \& Parker, D. (2002). A social psychological approach to driving violations in two Chinese cities. Transportation Research Part F: Traffic Psychology and Behaviour, 5 (4), 293-308.

Zuckerman, M. (2007). Sensation seeking and risky behavior. Washington, DC: American Psychological Association. 
Appendix

\begin{tabular}{|c|c|c|c|}
\hline Variables & $\mathrm{A}-\mathrm{SA} / \%$ & $\mathrm{M} / \mathrm{SD}$ & $\begin{array}{c}\text { Factor } \\
\text { Loading }\end{array}$ \\
\hline \multicolumn{4}{|l|}{ Sensation Seeking } \\
\hline I do avoid the competition in traffic $(\mathrm{R})$ & $61 / 18$ & $1.62 / .98$ & .70 \\
\hline I keep sufficient following distance (R) & $34 / 10$ & $1.44 / .74$ & .80 \\
\hline I do avoid unnecessary risks (R) & $35 / 10$ & $1.41 / .75$ & .86 \\
\hline I conform to the speed limits $(\mathrm{R})$ & $55 / 16$ & $1.65 / .83$ & .70 \\
\hline Cronbach's Alpha & & & .75 \\
\hline \multicolumn{4}{|l|}{ Aggressiveness } \\
\hline I horn to indicate my annoyance & $39 / 11$ & $1.70 / .80$ & .83 \\
\hline When I get angry at a driver, I give a chase & $24 / 7$ & $1.31 / .76$ & .83 \\
\hline Cronbach's Alpha & & & .54 \\
\hline \multicolumn{4}{|l|}{ Risk Perceptions } \\
\hline It is very likely that I involve traffic accident in the future & $146 / 42$ & $2.38 / .91$ & \\
\hline \multicolumn{4}{|l|}{ Media } \\
\hline As a driver I always interested in traffic related media campaigns & $215 / 62$ & $2.79 / .94$ & .81 \\
\hline As a driver I try to follow seminars on drivers & $147 / 42$ & $2.47 / .93$ & .85 \\
\hline As a driver I watch tv programs on safe driving & $212 / 61$ & $2.87 / .90$ & .75 \\
\hline Cronbach's Alpha & & & .73 \\
\hline \multicolumn{4}{|l|}{ Enforcement } \\
\hline $\begin{array}{l}\text { I obey traffic rules if I see a police car watching traffic from a } \\
\text { hidden position }\end{array}$ & $265 / 76$ & $3.10 / 1.08$ & .88 \\
\hline I obey traffic rules when I see a radar speed trap & $259 / 74$ & $3.07 / 1.07$ & .86 \\
\hline $\begin{array}{l}\text { I obey traffic rules when a police car is driving in traffic close to } \\
\text { me }\end{array}$ & $301 / 86$ & $3.43 / .93$ & .89 \\
\hline I obey the traffic rules when I notice cameras & $301 / 86$ & $3.42 / .94$ & .86 \\
\hline Cronbach's Alpha & & & .89 \\
\hline
\end{tabular}

$\mathrm{R}=$ Reverse; $\mathrm{A} / \mathrm{SA}=$ Agree/Strongly Agree 